\title{
Research on the Reform and Innovation Strategy of Environmental Design Basic Teaching
}

\author{
Chen Li \\ Xiamen University Tan Kah Kee College, Zhangzhou Fujian, China, 363105
}

Keywords: Environmental design; Basic teaching; Innovation strategy

Abstract: With the development of society, the traditional teaching mode can no longer meet the needs of the later professional courses. Therefore, the teaching reform of the basic curriculum is imperative. In the current course of the basic course of environmental art design, there are students' contempt for modeling courses, the content of teaching is out of line with professional positioning, and the teaching concept is backward. In this regard, colleges and universities should carry out targeted teaching reform experiments, closely following the characteristics of various professional directions. With commonality, reform the traditional teaching model with innovative methods and concepts. As a key professional course, the environmental design foundation must promote the reform of the course from the aspects of teaching methods, teaching content, teaching forms and assessment methods with a new educational concept, and continuously sum up experience in the reform to make it beneficial to students. The cultivation of comprehensive ability meets the needs of society for environmental engineering design and application talents.

\section{Introduction}

Environmental design has a certain representativeness in the comprehensive profession, theory and skills of the discipline. The environmental design profession is to plan the drawings, plans and projects through various practical links, and implement the professional construction system (Ali \& Bjørn, 2017). In the traditional teaching, teachers repeatedly pursue description and reproduction, thus neglecting the requirements of image and color, lack of professional knowledge of environmental design, resulting in blind learning professional courses for students, which is not good for the future development of students (Demetrios, Andrew, \& Dimitris, 2017). At present, the teaching methods are still carried out by traditional knowledge "irrigation". Teachers are mainly classrooms, and rational students like knowledge theory (Suh-Young, Jae-Uk, In-Beum, \& Jeehoon, 2017). The lack of independent and innovative logical thinking in teaching courses reduces the enthusiasm of students and leads to teaching effects (Vera, Nicole, \& Juan, 2017). Not good. Teachers should be reformed in the teaching process to improve the learning efficiency of students.

\section{Conceptual interpretation}

Environmental design has a certain representativeness in the comprehensive profession, theory and skills of the discipline. The environmental design profession is to plan the drawings, plans and 
projects through various practical links, and implement the professional construction system (Jef, Paul, Wim, \& Joost, 2017). In the traditional teaching, teachers repeatedly pursue description and reproduction, thus neglecting the requirements of image and color, lack of professional knowledge of environmental design, resulting in blind learning professional courses for students, which is not good for the future development of students (Isolda \& Guillaum, 2017). At present, the teaching methods are still carried out by traditional knowledge "irrigation". Teachers are mainly classrooms, and rational students like knowledge theory (Markus \& Ruth, 2017). The lack of independent and innovative logical thinking in teaching courses reduces the enthusiasm of students and leads to teaching effects (Florian \& Tim, 2017). Not good. Teachers should be reformed in the teaching process to improve the learning efficiency of students.

\section{Environmental Design Basic Teaching Reform Strategy}

In the first year, some schools set the first-grade courses as sketches, colors, shapes, and drawings after the students entered the school to strengthen the students' basic professional ability. The teaching methods of most colleges and universities are "indoctrination" teaching, which lacks mutual discussion between teachers and students and students, ignoring the ability of students to observe, analyze and solve problems and their ability to learn independently. In addition, some teachers in the teaching do not pay attention to the combination of design and practice, inspire students' ability to design independently, and simply emphasize the completion of homework, neglecting students' understanding of design when completing homework, especially the design creation. Most students have a negative attitude towards coping with assignments, rather than doing too much research on the design itself. This kind of teaching method is not conducive to cultivating students' creative ability and self-learning ability.

In the teaching of freshman, the basic course teaching system and curriculum should be arranged reasonably in the teaching of environmental design. It should not follow the traditional environmental design education curriculum system, and should enhance the cultivation of students' imagination and innovation ability, as well as architectural form, proportion, space, A deep understanding of the structural relationship. A number of corresponding courses on the theory of environment, architecture, and space design should be established to distance the basic course of environmental design from the major of painting. Optimize the teaching process, innovate the teaching environment, and the professional foundation course of environmental design should pay more attention to the teaching of the practical process. Students should have more opportunities to participate in the design of the actual project, and encourage students to bring the project of the internship to the school. Completed under the guidance of the teacher. In practice, students are allowed to apply theoretical knowledge to the actual design and enhance their innovative ability in design. In the classroom, after the teacher completes the teaching process, the students should organize their own discussions to complete the classroom study, fully mobilize the students' enthusiasm, and cultivate creative ability and independent learning ability. Focus on the integration and intersection of courses, and enhance the systematic teaching of professional basic courses. The individual courses in the basic course of environmental design are not isolated, but closely related. Therefore, we should pay attention to the integration and intersection of courses, and emphasize the teaching of professional basic courses. scientific. In the basic course of environmental design, the teaching content of design sketch is to cultivate students' ability to observe and shape the body through means of sketching. It is necessary to find the appropriate training method according to the characteristics of the students' own profession. You can do more color matching training in combination with the characteristics of environmental professional, pay attention to the connection and support between the basic course and the professional class. According to the direction of the 
environmental design profession, the content of the basic course is determined, and it is connected with the environmental professional design course to lay a solid foundation for the study of the subsequent design course, so as to improve the practical ability of the student design.

Establish a new form of classroom teaching, and there is a phenomenon of heavy professional and light foundation in the construction of environmental design professional courses. There is a serious disconnect between basic courses and professional courses. Therefore, it is necessary to lead the formation of design thinking and the mastery of design methods to build a new system of environmental design basic courses. In order to further clarify the purpose of the course, it is necessary to re-understand the content and form of the course. The teaching method emphasizes the direction of the big curriculum, emphasizes the integrity, comprehensiveness, and weakening unity: the combination of plane composition and color composition becomes the basis of design. It mainly solves the problem of two-dimensional space, emphasizes the commonality and unity of sketch and color, and does not leave, the difference lies in the number of performance factors. The purpose is mainly to solve the structural problems of the picture, pay attention to the richness of performance and the characteristics of students.

Each course is further clarified in terms of teaching content and form: enhancing the awareness of the subject. The subject is always treated as a whole, enhancing the initiative and interactivity of both the teacher and the student in the curriculum. The plane composition and color composition are organically combined, paying attention to the inheritance and change of content, avoiding one-sided problem solving, further strengthening the performance of points, lines and faces in language form, and highlighting the structural meaning of the picture. To enable students to better invest in the management of the picture, point and line, black and white gray, rhythm, rhythm become the dominant form factor of the picture, let students fully understand the essential meaning of the sketch, avoid form and form. Paying attention to the significance of color factors in the structure of the screen, we must let students maintain the central meaning of design sketches, and at the same time, through the color factors, through the training and application of color in hue, brightness, saturation and hue, solve the color The meaning of composition in the structure of the picture structure. Apply the whole and proper application to the curriculum; design color can further solve the composition of color in the structure of the picture structure through the practice of landscape sketching, pay attention to color induction and subjective adjustment, all starting from the picture structure. The adjustment of the course order and the changes in the content and form of the course bring not only a simple form change, but also the teaching practice based on theoretical research, showing an unusual learning face and learning effect. . Environmental design education consists of professional basic courses and professional design courses. The professional basic courses are the basic core courses of environmental design disciplines. Different teaching plans, teaching contents and research directions should be formulated according to the characteristics of different majors to make students clear. The direction of development has smoothly transitioned from professional basic courses to professional design courses. It also introduces the knowledge and production practice of relevant disciplines, organically integrates with theoretical knowledge, and forms a scientific and rational knowledge structure system, which lays a good foundation for students' future study and employment.

It is especially important to draw up the open teacher flow mechanism and formulate practical measures in a timely manner by referring to the "joint one introduction" approach. Union refers to the establishment of a shared faculty library for the environmental design majors of colleges and universities. In the practice teaching session, teachers of other colleges and universities who invite teachers to the library are required to form a dual tutor to carry out practical teaching. At the same time, the joint practice design between the school and the school can be carried out by using the extensive resources of the teacher library teachers. The introduction refers to inviting industry 
professionals to join the faculty to make up for the inadequacy of the teachers' social practice experience. Attempts to carry out teaching practice by school teachers and enterprise professionals, bring them into design projects, and make use of the rich design experience of the company to make practice Teaching has been expanded to the market direction, and it also helps outstanding students to obtain more employment opportunities. The open teacher flow mechanism needs to start from the actual situation of each university and establish corresponding supervision and management measures, which is based on the improvement of teaching quality, not just in form.

As the environmental design profession itself is a comprehensive discipline, the practical construction of environmental design projects is a complex process, comprehensive training for students, comprehensively improve students' comprehensive coping ability and practical design ability. It can effectively solve the bottleneck problem that students learn and the society, and the industry is out of touch.Reforming the teaching mode and seeking new breakthroughs, curriculum teaching is the foundation for realizing the goal of training art design talents. The traditional teaching mode is mainly based on theoretical narrative in the process of landscape design teaching, and then completed through virtual subject form. Say, everything is built on the assumptions. This model is teacher-led, focusing on the guidance and explanation of professional theoretical knowledge, ignoring the growth of students' independent thinking and individuality. The result is that teachers are physically and mentally exhausted, and students are negatively tired of learning. With regard to theory and practice, Rawls once put forward the "reflexive balance" in "Theory of Justice": "To judge the validity of a theory, to judge whether it really solves the problem, and to have a positive guiding significance for the actual needs. Constantly returning to practice and providing its rationality basis through practical actions.

Improve the quality of teachers in environmental design and enrich the content of teaching. Professional teachers are the main implementers of the teaching reform of environmental design, and play a leading role in the professional learning of students. The level of their ability to perform is crucial to the orderly implementation of teaching. important influence. Because the environmental design course has strong practicality, this requires teachers to have the "double-type" quality. In other words, as a professional teacher, it is necessary to have a perfect professional theoretical knowledge system, rich mathematical experience, and also have a high professional quality as a designer."Double-teacher" teachers can closely link theoretical teaching with engineering practice, effectively solve the practical problems of environmental design majors, provide students with the latest industry information in the classroom, and realize the learning content in teaching and the actual work of the design unit. Consistent.

\section{Conclusions}

The teaching reform of environmental design major must be based on the pursuit of social development. We must seriously consider the rational setting of the curriculum, establish a scientific and rational system as a guarantee, improve the quality of teaching, enhance the practical work, and cultivate innovative thinking. The purpose is to establish a professional talent training system with complete structure, system optimization and sound mechanism. Only in this way can the environmental art design profession adapt to the development needs of the times and society, and cultivate more outstanding design talents.

\section{References}

[1] Ali Torabi Haghighi,Bjørn Kløve. Design of environmental flow regimes to maintain lakes and wetlands in regions with high seasonal irrigation demand[J]. Ecological Engineering,2017,100.

[2] Demetrios Psaltopoulos,Andrew J. Wade,Dimitris Skuras,Martin Kernan,Emmanouil Tyllianakis,Martin Erlandsson. 
False positive and false negative errors in the design and implementation of agri-environmental policies: A case study on water quality and agricultural nutrients[J]. Science of the Total Environment,2017,575.

[3] Suh-Young Lee,Jae-Uk Lee,In-Beum Lee,Jeehoon Han. Design under uncertainty of carbon capture and storage infrastructure considering cost, environmental impact, and preference on risk[J]. Applied Energy,2017,189.

[4] Vera Ferrón Vilchez,Nicole Darnall,Juan Alberto Aragón Correa. Stakeholder influences on the design of firms' environmental practices [J]. Journal of Cleaner Production,2017,142.

[5] Jef R. Peeters,Paul Vanegas,Wim Dewulf,Joost R. Duflou. Economic and environmental evaluation of design for active disassembly [J]. Journal of Cleaner Production,2017,140.

[6] Isolda Agustí-Juan,Guillaume Habert. Environmental design guidelines for digital fabrication[J]. Journal of Cleaner Production, 2017,142.

[7] Markus Ahola,Ruth Mugge. Safety in passenger ships: The influence of environmental design characteristics on people's perception of safety [J]. Applied Ergonomics,2017,59.

[8] Florian Baumann,Tim Friehe. Design standards and technology adoption: welfare effects of increasing environmental fines when the number of firms is endogenous[J]. Environmental Economics and Policy Studies, 2017, 19(2). 